STUDIA PRAWNO-EKONOMICZNE, t. CIV, 2017

PL ISSN 0081-6841; e-ISSN 2450-8179 $\quad$ s. 223-234

DOI: 10.26485/SPE/2017/104/12

Grażyna BORYS*

Wojciech KRAWIEC**

\title{
UPRAWNIENIA ZBYWALNE DO EMISJI GAZÓW CIEPLARNIANYCH JAKO INNOWACJA FINANSOWA
}

\section{(Streszczenie)}

Przedmiotem opracowania są uprawnienia zbywalne do emisji gazów cieplarnianych, które, z natury rzeczy, są kluczowym elementem konstrukcji europejskiego systemu handlu emisjami, natomiast jego celem stała się identyfikacja, a następnie analiza formalnych (prawnych) i pozaformalnych przesłanek postrzegania uprawnień do emisji w kategoriach innowacji finansowych o zasięgu regionalnym (europejskim) i lokalnym (krajowym). Identyfikacja została poprzedzona naświetleniem istoty uprawnień i krótką ich charakterystyką, wzbogaconą elementami statystyki polskich aukcji uprawnień do emisji gazów cieplarnianych.

Słowa kluczowe: handel emisjami; uprawnienia zbywalne do emisji; innowacje finansowe Klasyfikacja JEL: G10, G18, O31, Q48, Q54

\section{Wstęp}

Dzisiaj nie ma już wątpliwości, że zarówno kraje wysoko rozwinięte, jak i kraje rozwijające się zmierzają w kierunku gospodarki niskoemisyjnej, która stwarza szanse na rozwiązanie problemu globalnego ocieplenia. Kamieniem milowym na drodze ograniczenia emisji gazów cieplarnianych (ang. greenhouse gases - GHG) było przyjęcie w 1997 r., w czasie III Konferencji Stron Ramowej Konwencji Narodów Zjednoczonych w sprawie zmian klimatu, Protokołu z Kioto'. Stro-

* Prof. dr hab., Uniwersytet Ekonomiczny we Wrocławiu; e-mail: gborys@ae.jgora.pl

** Dr, Uniwersytet Ekonomiczny we Wrocławiu; e-mail: wojciech.krawiec@ue.wroc.pl

1 Protokót z Kioto do Ramowej Konwencji Narodów Zjednoczonych w sprawie zmian klimatycznych, sporzadzony w Kioto 11 grudnia 1997 r. (Dz.U. z 2013 r., nr 5, poz. 1684). 
ny podpisujące Protokół zadecydowały m.in., że redukcja emisji GHG ma się odbywać za pomocą międzynarodowego handlu emisjami (ang. International Emission Trading - IET). W związku z dołączeniem Unii Europejskiej do Stron Protokołu, podjęła ona własną inicjatywę stworzenia europejskiego systemu handlu uprawnieniami do emisji gazów cieplarnianych (European Union Emissions Trading System - EU ETS). Wdrożenie EU ETS do praktyki gospodarczej krajów tworzących Unię nastapiło 1 stycznia 2005 r. na mocy dyrektywy 2003/87/WE Parlamentu Europejskiego i Rady z dnia 13 października 2003 r. ustanawiającej system handlu przydziałami emisji gazów cieplarnianych we Wspólnocie oraz zmieniającej dyrektywę Rady 96/61/WE², choć pierwszą transakcję kontraktem forward na uprawnienia zawarto już w 2003 r. ${ }^{3}$

Przedmiotem opracowania są uprawnienia zbywalne do emisji gazów cieplarnianych, które, z natury rzeczy, są kluczowym elementem konstrukcji europejskiego systemu handlu emisjami, natomiast jego celem stała się identyfikacja, a następnie analiza formalnych (prawnych) i pozaformalnych przesłanek postrzegania uprawnień do emisji w kategoriach innowacji finansowych o zasiegu regionalnym (europejskim) i lokalnym (krajowym). Należy zastrzec, że ograniczone ramy opracowania nie pozwoliły na odniesienie się do problemów, jakie rodzi praktyka funkcjonowania uprawnień do emisji GHG.

W procesie analitycznym posłużono się metodą dedukcji, metodą analizy aktów prawnych oraz metodą krytycznej analizy literatury przedmiotu.

\section{Istota i ogólna charakterystyka uprawnień zbywalnych do emisji gazów cieplarnianych}

Powietrze atmosferyczne jest pierwotnym elementem naszego życia i depozytem materiałów budulcowych życia. Każdy człowiek związany jest z nim poprzez skomplikowaną, dynamiczną strukturę oddziaływań, co sprawia, że powietrze jest dobrem niewykluczalnym z „konsumpcji” (nonexcludable), a zatem dobrem publicznym ${ }^{4}$. Równocześnie pełni ono funkcję magazynowania, przekazywania, filtrowania i izolacji cieplnej, co powoduje, że z powietrzem związane są różne problemy środowiskowe, będące wynikiem zaspokajania bytowych i gospodar-

2 Dz. Urz. WE L 275 z 25.10.2003 r.

3 P. Ambrosi, K. Capoor, State and Trends of the Carbon Market 2007, The World Bank, Washington D.C., May 2007.

4 W.J. Baumol, Welfare Economics and the Theory of the State, Harvard University Press, Cambridge, Mass. 1952, s. 11. 
czych potrzeb człowieka ${ }^{5}$. Kłopot $\mathrm{z}$ ich rozwiązaniem polega na tym, że jest ono dobrem niepodzielnym (amorficznym), co oznacza, że niemożliwe jest takie jego rozgraniczenie, aby w ramach określonych granic przypisać sferę uprawnień do korzystania z niego konkretnemu podmiotowi, który przejąłby równocześnie odpowiedzialność za poziom jego zanieczyszczenia. Reasumując, powietrze atmosferyczne jest klasycznym dobrem publicznym, a dodatkowo niepodzielnym. Konkluzja ta ma istotne znaczenie ekonomiczne. „Konsumpcja” powietrza nie może podlegać mechanizmowi rynkowemu, który opiera się na indywidualnej odpłatności, czyli cenie płaconej za nabycie wykluczalnego i podzielnego dobra.

Skoro nie można wydzielić mas powietrza celem przypisania poszczególnym podmiotom kwantyfikowalnych praw do korzystania z nich w drodze transakcji rynkowych, w działaniach ochronnych przed nadmiernym jego zanieczyszczeniem można zastosować najprostsze rozwiązanie odwrotne - ustanowić obowiązki związane z korzystaniem z powietrza jako odbiornika szkodliwych emisji, wyrażonych w formie administracyjnych limitów emisji-pozwoleń na emisję, których przekroczenie skutkuje sankcjami prawnofinansowymi. Zamiast rynkowego mechanizmu dostępu do powietrza jako dobra o charakterze fizykalnym można ustanowić „dobro” (pozwolenie) o charakterze niefizykalnym, dające się przypisać na wyłączność, i którego przypisanie konkretnemu podmiotowi gospodarczemu umożliwia mu korzystanie z amorficznego dobra fizykalnego. Niestety, jak wykazała praktyka, alokacja tego „dobra” w gospodarce generuje wysokie koszty administracyjne i towarzyszy jej asymetria informacji o niezbędnych nakładach na przeprowadzanie programów ograniczania emisji zanieczyszczeń pomiędzy publicznym (administracyjnym) decydentem a poszczególnymi emitentami, co stanowi źródło poważnych nieefektywności w gospodarce.

W poszukiwaniu bardziej efektywnego rozwiązania stworzono zbywalne, skwantyfikowane uprawnienia do emisji zanieczyszczeń dla operatorów źródeł emisji w ściśle określonych okresach sprawozdawczych - umarzalne po ich zakończeniu. Takie uprawnienia nie tylko odpowiadają określonej wielkości dopuszczalnej emisji, ale mogą być także przedmiotem obrotu, przede wszystkim pomiędzy operatorami. Zbywalność uprawnień do emisji umożliwia osiąnięcie redukcji emisji w najbardziej efektywny ekonomicznie sposób (usuwa asymetrię informacji oraz umożliwia wybór optymalnego terminu przeprowadzenia programu redukcyjnego). Poszczególni uczestnicy systemu handlu uprawnieniami

5 M. Kramer, M. Urbaniec, A. Kryński (red.), Międzynarodowe zarządzanie środowiskiem, t. 1: Interdyscyplinarne założenia proekologicznego zarządzania przedsiębiorstwem, C.H. Beck, Warszawa 2004, s. 6. 
indywidualnie dokonują oceny, czy bardziej opłacalne jest dla nich podjęcie działań służących ograniczeniu emisji w danym okresie sprawozdawczym, czy też tańsze będzie zakupienie na rynku brakujących, niezbędnych do umorzenia uprawnień od podmiotów dysponujących ich nadwyżką, które to nadwyżki powstawać mogą w szczególności właśnie wskutek podjęcia działań zmniejszających emisję. Umorzenie uprawnień jest warunkiem uniknięcia kary pieniężnej.

Powyższy konstrukt został wykorzystany do budowy EU ETS. Należy jednak podkreślić, że system podlega systematycznemu (z okresu na okres rozliczeniowy) doskonaleniu. Do tej pory objęto nim trzy takie okresy: 2005-2007; 2008-2012; 2013-2020. Stąd, w poniższym opisie uprawnień do emisji GHG objętych EU ETS wskazano tylko te ich charakterystyki, które mają moc obowiązującą lub które wskazują kierunek ich ewolucji i mają znaczenie z punktu widzenia podstawowego celu badawczego.

Punktem wyjścia opisu uprawnień jest oczywiście ich zdefiniowanie. W myśl art. 3 dyrektywy 2003/87/WE ,uprawnienie” oznacza uprawnienie do emisji jednej tony gazu cieplarnianego stanowiącego odpowiednik dwutlenku węgla w danym okresie, ważne wyłącznie dla celów tejże dyrektywy i zbywalne zgodnie z jej postanowieniem. Charakter prawny uprawnień do emisji na gruncie prawa unijnego determinuje jeszcze tzw. Czwarte Rozporządzenie Rejestrowe ${ }^{6}$ oraz dyrektywa MiFID II. Rozporządzenie w art. 40 stanowi, że uprawnienie jest zamiennym, niematerialnym instrumentem, który jest zbywalny na rynku, przy czym niematerialny charakter uprawnienia oznacza, że zapis w rejestrze Unii stanowi wystarczające potwierdzenie prima facie prawa własności uprawnienia oraz potwierdzenie wszelkich innych kwestii, które zgodnie z rozporządzeniami są kierowane lub mogą być kierowane do rejestru Unii. Z kolei, zamienność uprawnienia oznacza, że wszelkie obowiązki dotyczące zwrotu lub restytucji, które mogą dotyczyć uprawnienia zgodnie z prawem krajowym, mają zastosowanie do uprawnienia tego samego rodzaju. Powyższe dwie definicje stanowią podstawę wyróżnienia najważniejszych cech uprawnień do emisji GHG, a mianowicie:

- są one denominowane w jednej, wspólnej jednostce, jaką jest $1 \mathrm{Mg}$ dwutlenku węgla;

- funkcjonują wyłącznie w formie elektronicznego zapisu w rejestrze Unii;

6 Rozporządzenie Komisji (UE) Nr 389/2013 z dnia 2 maja 2013 r. ustanawiające rejestr Unii zgodnie z dyrektywą 2003/87/WE Parlamentu Europejskiego i Rady, decyzjami nr 280/2004/ WE Parlamentu Europejskiego i Rady oraz uchylające rozporządzenie Komisji (UE) nr 920/2010 i nr 1193/2011 (Dz. Urz. UE L 122 z 3.05.2013 r.). 
- mają zdolność do bycia kupowanymi, zbywalnymi i posiadanymi przez dowolny podmiot Unii Europejskiej, posiadający otwarty rachunek służący ich zapisowi;

- ich zbywalność ograniczona jest tylko wymogami nałożonymi przez dany lokalny (krajowy) system prawny.

Z kolei, dyrektywa MiFID II $^{7}$ zalicza ,uprawnienia do emisji obejmujące dowolne jednostki uznane za spełniające wymogi dyrektywy 2003/87/WE (system handlu uprawnieniami do emisji)" do instrumentów finansowych. Zaliczenie to odbyło się poprzez proste dopisanie uprawnień do istniejącego wcześniej, na gruncie dyrektywy MiFID, katalogu instrumentów finansowych.

Kierunkowym mechanizmem alokacji uprawnień, począwszy od 2013 r., staje się regulowany rynek aukcyjny. Generalnie, aukcje odbywają się na wspólnej platformie aukcyjnej, wybranej w procedurze udzielenia zamówienia publicznego ustalonego rozporządzeniem Komisji (WE, Euroatom) nr 2342/2002 z dnia 3 grudnia 2002 r., ustanawiającego szczegółowe zasady wykonywania rozporządzenia Rady (WE, Euroatom) nr 1605/2002 w sprawie rozporządzenia finansowego mającego zastosowanie do budżetu ogólnego Wspólnot Europejskich ${ }^{8}$. Wybraną platformą jest platforma Europejskiej Giełdy Energii EEX z siedzibą w Lipsku. Równocześnie przewidziano możliwość niekorzystania (out-put) ze wspólnej platformy aukcyjnej i wyznaczenia własnych platform aukcyjnych - również w procedurze udzielenia zamówienia publicznego. Z możliwości tej skorzystała m.in. Polska. Polskie aukcje odbywają się na odrębnych sesjach na platformie EEX.

Przedmiotem obrotu aukcyjnego są uprawnienia do emisji:

- EUA (European Union Allowances) - wydawane operatorom instalacji stacjonarnych,

- EUAA (European Union Aviation Allowance) - wydawane operatorom operacji lotniczych.

Pierwsza polska aukcja uprawnień do emisji gazów cieplarnianych miała miejsce 16 września 2013 r. Od tego czasu do 30 marca 2016 r. przeprowadzono 26 aukcji uprawnień dla operatorów instalacji stacjonarnych oraz 2 aukcje uprawnień dla operatorów lotniczych (tabela 1).

7 Dyrektywa Parlamentu Europejskiego I Rady 2014/65/UE z dnia 15 maja 2014 r. w sprawie rynków instrumentów finansowych oraz zmieniająca dyrektywę 2002/92/WE i dyrektywę 2011/61/UE (Dz. Urz. UE L 173 z 12.06.2014 r.).

8 Dz. Urz. UE L 357 z 31.12.2002 r. 


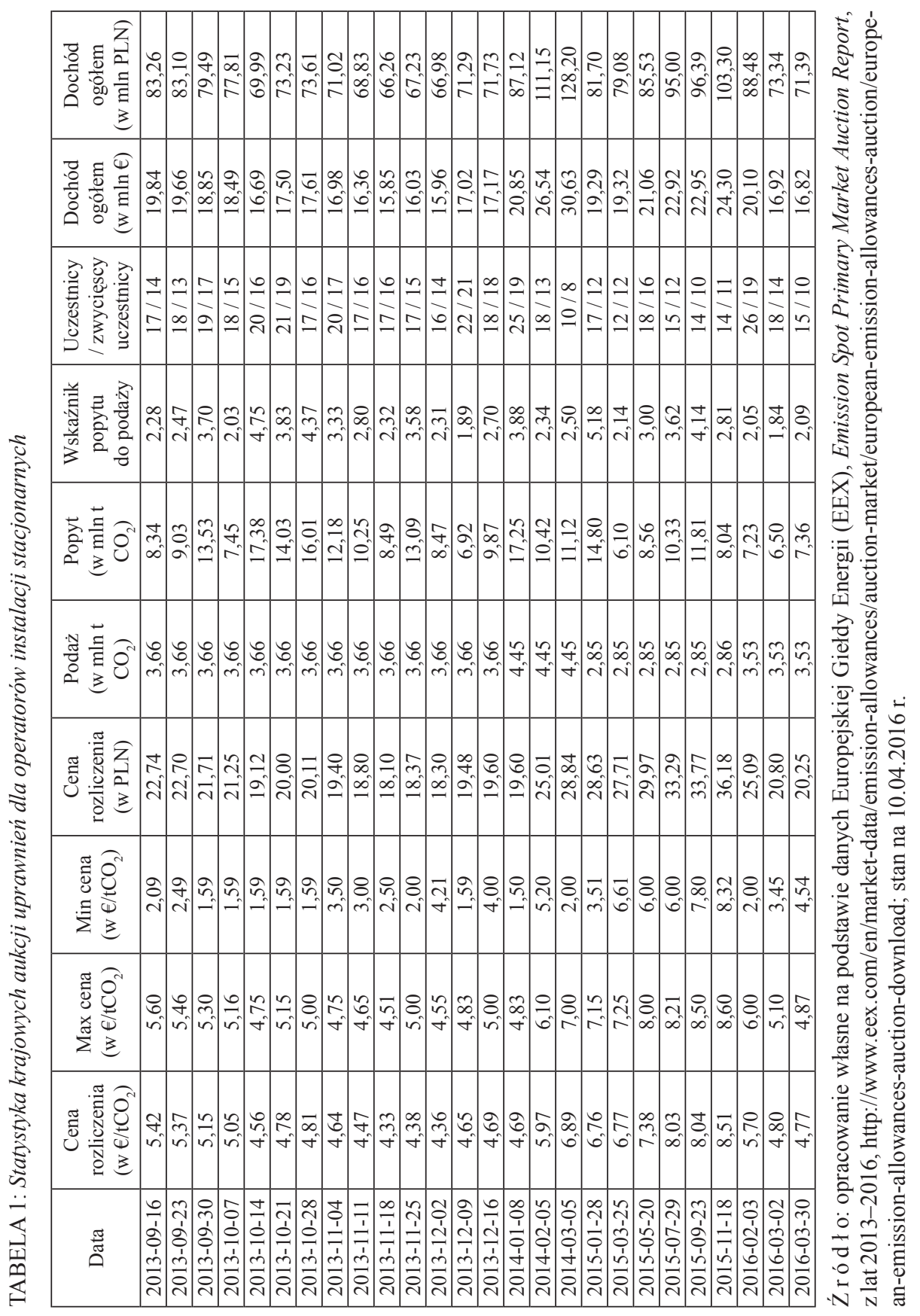


Jak można zauważyć, bez względu na liczbę aukcji oraz wielkość podaży, każda aukcja charakteryzowała się wysokim poziomem redukcji. Popyt na uprawnienia do emisji $\mathrm{CO}_{2}$ średnio trzykrotnie przewyższał podaż, a zdarzały się aukcje, podczas których wskaźnik ten oscylował nawet w granicach 5 (14.10.2013 r.; 28.01.2015 r.). Sytuacja ta miała również swoje odzwierciedlenie w relacji pomiędzy liczbą uczestników aukcji a liczbą zwycięskich uczestników aukcji. Tylko podczas jednej aukcji (16.12.2013 r.) zdarzyło się, że wszyscy uczestnicy aukcji nabyli uprawnienia - aczkolwiek wskaźnik redukcji popytu wyniósł wtedy 2,70. Podczas wszystkich pozostałych aukcji część uczestników nie nabyła uprawnień, a liczba przegranych uczestników stanowiła nawet $1 / 3$ wszystkich biorących udział w aukcji.

W trakcie wszystkich 16 aukcji uprawnień dla operatorów instalacji stacjonarnych cena rozliczenia kształtowała się w przedziale od 4,33€ do $8,51 €$ (18,10 PLN - 36,18 PLN).

Najniższą wartość cena rozliczenia osiągnęła 18 listopada 2013 r., zaś najwyższą 18 listopada 2015 r. Przeciętnie kupujący płacili za uprawnienie do emisji 1 tony $\mathrm{CO}_{2}-5,58 €(23,43 \mathrm{PLN})$. Warto dodać, że cena rozliczenia podczas każdej aukcji ustalana była na poziomie zbliżonym do zaoferowanej ceny maksymalnej.

Podczas pięciu aukcji cena rozliczenia była bliska zaoferowanej cenie minimalnej. W pozostałych przypadkach odchylenia między ceną rozliczenia a ceną minimalną wynosiły nawet $3 €$.

Poza aukcjami uprawnień dla operatorów instalacji stacjonarnych przeprowadzono dotychczas także dwie aukcje uprawnień dla operatorów instalacji lotniczych. Pierwsza z tych aukcji miała miejsce 25 marca 2015 r., zaś druga 17 lutego 2016 r. Podczas pierwszej aukcji do sprzedaży przeznaczonych zostało 433,50 tys. uprawnień, zaś całkowite zapotrzebowanie zgłoszone przez uczestników aukcji wyniosło 1,81 mln uprawnień. Cena rozliczeniowa została ustalona na poziomie $6,88 €(28,16$ PLN). Podczas drugiej aukcji do sprzedaży przeznaczono 120,00 tys. uprawnień, ale całkowite zapotrzebowanie przez operatorów instalacji lotniczych osiagnęło poziom 1,66 mln uprawnień. Tym samym popyt był prawie 14-krotnie większy niż liczba uprawnień zaoferowanych do sprzedaży. Cena rozliczeniowa została ustalona na poziomie 4,80€ (21,07 PLN). Obie aukcje cieszyły się ogromnym zainteresowaniem. W pierwszej z nich uczestniczyło 11 firm, z tym że sukcesem zakończyły tylko 2 z nich. W aukcji z 2016 r. udział wzięło 12 podmiotów, zaś transakcje zawarły także tylko 2 .

Dochody ze sprzedaży uprawnień do emisji zanieczyszczeń GHG są dochodem budżetowym państwa członkowskiego, które zaoferowało je do sprzedaży, w ramach algorytmu wyznaczanego przez Komisję Europejską. Mają one 
charakter dochodów znaczonych w tym sensie, że sprecyzowano kierunek ich wydatkowania. Całkowity dochód polskiego budżetu z aukcji uprawnień dla operatorów instalacji stacjonarnych osiagnął wartość 505,71 $\mathrm{mln} €$ (2,12 mld PLN). Natomiast całkowity dochód z aukcji uprawnień dla operatorów instalacji lotniczych wyniósł 3,56 mln $€(15,45 \mathrm{mln}$ PLN).

Wtórny obrót uprawnieniami do emisji GHG może natomiast odbywać się zarówno na rynkach regulowanych, jak i nieregulowanych (OTC) oraz za pośrednictwem transakcji bilateralnych.

\section{Przesłanki postrzegania uprawnień do emisji gazów cieplarnianych w kategoriach innowacji finansowych}

Obecnie, niemal powszechnie, innowacje finansowe kojarzone są z nowymi rozwiązaniami w którymkolwiek z elementów systemu finansowego w ujęciu funkcjonalnym, którego twórcą i propagatorem jest R.C. Merton ${ }^{9}$. W świetle tego podejścia system finansowy obejmuje instrumenty finansowe i usługi finansowe oraz sieć ich rynków, pośredników finansowych oraz innych instytucji finansowych, dzięki którym realizowane są wszystkie plany finansowe gospodarstw domowych, przedsiębiorstw i rządu. Zdaniem Z. Bodie i R.C. Mortona, innowacje finansowe nie są planowane przez żadne centralne władze, ale są wynikiem indywidualnych działań przedsiębiorców i firm. Głównymi siłami ekonomicznymi stojącymi za innowacjami finansowymi są te same siły, które kryją się za każdą inną innowacją. Są to siły rynkowe - dążenie do osiagnięcia własnych interesów, co przyczynia się do promowania interesów społeczeństwa bardziej efektywnie ${ }^{10}$.

Analiza konstrukcji uprawnień do emisji GHG wprowadza pewne korekty w zaprezentowanym stanowisku. Po pierwsze, należy zauważyć, że przesłanki postrzegania uprawnień do emisji w ramach EU ETS w kategoriach innowacji finansowych (nowości) mają charakter zarówno czysto formalny (prawny), jak i pozaformalny - związany z funkcjami innowacji w rynkowym (prywatnym) systemie finansowym. Niewatpliwie przesłanką natury formalnej postrzegania uprawnień jako innowacji finansowych jest wzmiankowane już zaliczenie ich, na gruncie dyrektywy MiFID II, do instrumentów finansowych w drodze rozszerzenia Załącznika I Sekcji C o nowy punkt 11 - pojawił się całkowicie nowy instrument

9 R.C. Merton, A Functional Perspective of Financial Intermediation, Financial Management 1995/24, s. 26.

10 Z. Bodie, R.C. Merton, Finanse, PWE, Warszawa 2003, s. 65. 
finansowy, który w procesie implementacji prawa europejskiego przeniesiony zostanie do krajowych systemów finansowych. Jak się wydaje, podstawową przyczyną tego prostego zabiegu technicznego była potrzeba poddania rynku uprawnień nadzorowi finansowemu. Jednak status prawny uprawnień ostatecznie będzie musiał być rozstrzygnięty na gruncie konkretnego prawa krajowego rządzącego obrotem tymi uprawnieniami - instrumenty finansowe obejmują wiele ich podtypów. Problem ten dostrzeżony już został w polskiej literaturze przedmiotu. W 2015 r. na Wydziale Prawa i Administracji Uniwersytetu Warszawskiego obroniona została praca doktorska, w której jej Autor - Krzysztof Gorzelak - pozytywnie zweryfikował hipotezę, że na gruncie polskiego prawa uprawnienia do emisji GHG stanowią nową, dość nietypową klasę papierów wartościowych ${ }^{11}$.

Cechę „,nietypowości” nowej klasy papierów wartościowych należy rozpatrywać przede wszystkim przez pryzmat regulacji objętych tytułem XXXVII kodeksu cywilnego - Przekaz i papiery wartościowe ${ }^{12}$. Otóż, regulacja kodeksowa odnosi się w zasadzie do papierów wartościowych reprezentujących prawa cywilnoprawne. Konstrukcja uprawnień do emisji przemawia jednak za ich uznawaniem za publiczne prawa podmiotowe o nietypowej cesze zbywalności, przy czym ta zbywalność jest immanentną cechą uprawnień, a nie tylko ich wyróżnikiem. Nie są też uprawnienia prywatnym prawem podmiotowym powstającym jako następstwo wykreowania stosunku administracyjnoprawnego. $Z$ tego względu można powiedzieć, że regulacja uprawnień do emisji GHG stanowi obszar, w którym prawo administracyjne „styka się" z prawem prywatnym lub że publiczny system finansowy zazębia się z rynkowym systemem finansowym. Co więcej, uprawnienia do emisji zostały zaprojektowane i są wykorzystywane do realizacji zadań publicznych przez władze publiczne na szczeblu ponadpaństwowym i krajowym. Obszarem potencjalnych innowacji nie musi więc być, w świetle tej obserwacji empirycznej, wyłącznie prywatny system finansowy, a głównymi siłami stojącymi za nimi nie muszą być jedynie siły rynkowe. Kreatorem innowacji finansowych może być także władza publiczna wykorzystująca siły rynkowe w procesie realizacji własnych zadan - w rozpatrywanym przypadku w ochronie klimatu.

W literaturze klasyfikuje się papiery wartościowe według różnych kryteriów, w tym między innymi z punktu widzenia charakteru prawa reprezentowanego przez dany papier. Stosując to kryterium, wyróżnia się papiery wartościowe inkorporujące wierzytelności oraz papiery reprezentujące prawa udziałowe.

11 K. Gorzelak, Uprawnienia do emisji jako przedmiot obrotu I zabezpieczeń, praca doktorska, 20DOKTORSKA\%28wersja\%.pdf?sequence $=1$

12 Ustawa z dnia 23 kwietnia kodeks cywilny, t.j. Dz.U. z 2014 r., poz. 121 z późn. zm. 
Uprawnień do emisji nie można zaliczyć oczywiście ani do jednej, ani do drugiej grupy, stąd pogląd, że stanowią one nową klasę papierów wartościowych. Skoro ich podstawowa funkcja sprowadza się do dokonania operacji ich umorzenia, można zaryzykować tezę, że inkorporują one prawo do „uniknięcia kary pieniężnej" za odprowadzanie zanieczyszczeń do powietrza. Należy podkreślić, że przepisy kodeksowe nie tworzą żadnych barier w zakresie kreowania walorów reprezentujących w zasadzie każde prawo.

Nowością uregulowań dystrybuowania uprawnień do emisji GHG w ramach EU ETS - postrzeganych jako papiery wartościowe - jest mechanizm aukcyjny, który tworzy pewne gwarancje dostępu do rynku dla mniejszych podmiotów - przedsiębiorstw sektora MŚP.

Kluczowe znaczenie w identyfikacji pozaformalnych przesłanek postrzegania uprawnień do emisji w kategoriach innowacji finansowych mają zgodnie z obowiązującą doktryna, funkcje spełniane przez nie w systemie finansowym, które też determinują $\mathrm{w}$ dużym stopniu korzyści związane $\mathrm{z}$ ich funkcjonowaniem. W literaturze przedmiotu sformułowane zostały dwie teorie innowacji finansowych: popytowa i podażowa. Popytowa teoria innowacji jako główne źródła nowych rozwiązań w obrębie systemu finansowego wskazuje niedoskonałości rynku finansowego wynikające głównie z asymetrii informacji, kosztów agencji oraz kosztów transakcyjnych. Te niedoskonałości rynkowe kreują popyt na rozwiązania pozwalające uczestnikom rynku na ograniczenie ich negatywnych konsekwencji. Z kolei, podażowa teoria innowacji finansowych ich źródło postrzega w zwiększonej aktywności instytucji finansowych dążących do zwiększenia swojej przewagi konkurencyjnej. Instytucje oferują swoim klientom zwykle innowacje agresywne $\mathrm{w}$ formie nowych instrumentów inwestowania, oszczędzania, finansowania czy realizacji płatności ${ }^{13}$. Niekiedy utrzymuje się nawet, że skuteczne wprowadzanie innowacji finansowych wymaga wykorzystania luk w regulacjach ${ }^{14}$.

Traktowanie uprawnień do emisji jako innowacji finansowych nie znajduje uzasadnienia na gruncie żadnej z tych teorii, ponieważ innowacje na gruncie tych teorii kojarzone są tylko z rynkowym systemem finansowym, o czym była mowa wcześniej, i abstrahują od zadań publicznych w sferze realnej. Nie jest to jednoznaczne ze stwierdzeniem, że nie są one innowacjami finansowymi. Uprawnienia do emisji stanowią, jak się wydaje, ,nietypową innowację finansową”. Została ona

13 J. Blach, Innowacje i ich znaczenie we wspótczesnym systemie finansowym - identyfikacja i systematyzacja problemu, Finansowy Kwartalnik Internetowy „e-Finanse” 2011/7/3, s. 21-22.

14 I. Kidacka, Finanse zintegrowane. Sekurytyzacja, struktury finansowe, Difin, Warszawa 2006, s. 24. 
wykreowana w związku z poważnym problemem sfery realnej - ochroną klimatu, bądź szerzej, sposobem wykonywania uprawnień właścicielskich przez suwerena publicznego w stosunku do fizykalnego dobra publicznego o charakterze niepodzielnym (powietrza atmosferycznego). Innowację tę należałoby usytuować na pograniczu publicznego i prywatnego systemu finansowego. Umożliwia ona pokonanie bariery informacyjnej w sektorze publicznym, obniża koszty administracyjne systemu kontroli emisji, zwiększa efektywność nakładów na redukcję gazów cieplarnianych oraz pozwala zgromadzić fundusze publiczne na ochronę klimatu i przygotowanie się do zmian klimatycznych, przy zastosowaniu zasady: „zanieczyszczający płaci”.

\section{Podsumowanie}

Identyfikacja i analiza przesłanek postrzegania zbywalnych zezwoleń do emisji GHG w ramach EU ETS w kategoriach innowacji finansowych - najpierw przez unijnego ustawodawcę, a następnie też przez doktrynę - prowadzi do trzech generalnych wniosków. Po pierwsze, falsyfikuje tezę, że do uniknięcia tragedii dóbr publicznych konieczne są ,rządy żelaznej ręki”"15, po drugie, dowodzi, że obszarem kreacji potencjalnych innowacji finansowych nie jest wyłącznie rynkowy sektor finansowy, a po trzecie, przekonuje, że problem budowy spójnej i przystającej bardziej do rzeczywistości gospodarczej całościowej teorii innowacji finansowych jest problemem otwartym.

\section{Bibliografia}

\section{Akty prawne}

Dyrektywa 2003/87/WE Parlamentu Europejskiego i Rady z dnia 13 października 2003 r. ustanawiająca system handlu przydziałami emisji gazów cieplarnianych we Wspólnocie oraz zmieniającej dyrektywę Rady 96/61/WE (Dz. Urz. WE L 275 z 25.10.2003 r.).

Dyrektywa Parlamentu Europejskiego I Rady 2014/65/UE z dnia 15 maja 2014 r. w sprawie rynków instrumentów finansowych oraz zmieniająca dyrektywę 2002/92/WE i dyrektywę 2011/61/UE (Dz. Urz. UE L 173 z 12.06.2014 r.).

Protokót z Kioto do Ramowej Konwencji Narodów Zjednoczonych w sprawie zmian klimatycznych, sporzadzony w Kioto 11 grudnia 1997 r. (Dz.U. z 2013 r., nr 5, poz. 1684).

Rozporządzenie Komisji (WE, Euroatom) nr 2342/2002 z dnia 23 grudnia 2002 r. ustanawiającego szczegółowe zasady wykonywania rozporządzenia Rady (WE, Euroatom) nr 1605/2002 w sprawie rozporządzenia finansowego mającego zastosowanie do budżetu ogólnego Wspólnot Europejskich (Dz. Urz. UE L 357 z 31.12.2002 r.).

15 R.L. Heilbroner, An Inquiry Into the Human Prospect, Norton, New York 1974, s. 74. 
Rozporządzenie Komisji (UE) Nr 389/2013 z dnia 2 maja 2013 r. ustanawiające rejestr Unii zgodnie z dyrektywą 2003/87/WE Parlamentu Europejskiego i Rady, decyzjami nr 280/2004/WE Parlamentu Europejskiego i Rady oraz uchylające rozporządzenie Komisji (UE) nr 920/2010 i nr 1193/2011 (Dz. Urz. UE L 122 z 3.05.2013 r.).

Ustawa z dnia 23 kwietnia kodeks cywilny (t.j. Dz.U. z 2014 r., poz. 121 z późn. zm.).

\section{Opracowania}

Ambrosi Philippe, Capoor Karan, State and Trends of the Carbon Market 2007, The World Bank, Washington D.C., May 2007.

Baumol William J., Welfare Economics and the Theory of the State, Harvard University Press, Cambridge, Mass. 1952.

Bodie Zwi, Merton Robert C., Finanse, PWE, Warszawa 2003.

Błach Joanna, Innowacje i ich znaczenie we współczesnym systemie finansowym - identyfikacja i systematyzacja problemu, Finansowy Kwartalnik Internetowy „e-Finanse” 2011/7/3.

Kramer Matthias, Urbaniec Maria, Kryński Andrzej (red.), Międzynarodowe zarządzanie środowiskiem, t. 1: Interdyscyplinarne założenia proekologicznego zarządzania przedsiębiorstwem, C.H. Beck, Warszawa 2004.

Gorzelak Krzysztof, Uprawnienia do emisji jako przedmiot obrotu I zabezpieczeń, praca doktorska, 20DOKTORSKA\%28wersja\%.pdf? sequence $=1$

Heilbroner Robert L., An Inquiry Into the Human Prospect, Norton, New York 1974.

Kidacka Izabela, Finanse zintegrowane. Sekurytyzacja, struktury finansowe, Difin, Warszawa 2006.

Merton Robert C., A Functional Perspective of Financial Intermediation, Financial Management 1995/24.

\section{Strony internetowe}

http://www.eex.com/en/market-data/emission-allowances/auction-market/european-emission-allowances-auction/european-emission-allowances-auction-download; Emission Spot Primary Market Auction Report, z lat 2013-2016; stan na 10.04.2016 r.

\section{Grażyna BORYS, Wojciech KRAWIEC}

\section{TRADEABLE GREENHOUSE GAS DISCHARGE PERMITS AS A FINANCIAL INNOVATION}

\section{( Sum mary)}

Tradeable greenhouse gas discharge permits are the subject of the study since, by nature, they represent the key component of the European emission trading scheme, whereas the purpose of the study is the identification and also the analysis of formal (legal) and non-formal reasons for approaching trading permits as financial innovations of regional (European) range and local (national) range. The identification was conducted by presenting the essence of the discussed permits and their brief characteristics, supported by the statistical elements from Polish auctions of GHG discharge permits.

Keywords: emission trading; tradeable allowances for emission; financial innovation 